\title{
MACHINE LEARNING PREDIKSI KEBANGKRUTAN MENGGUNAKAN ALTMAN Z-SCORE
}

\author{
Bambang Siswoyo*1, Encep.sse ${ }^{2}$,Firman ${ }^{3}$ \\ ${ }_{1,2,3}$ STKOM Al-Ma'soem

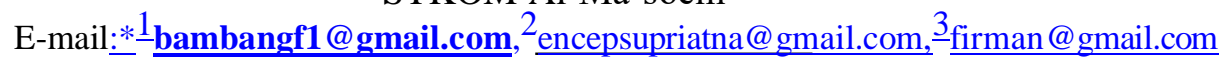

\begin{abstract}
Abstrak
Industri manufaktur adalah salah satu industry yang sangat memperhatikan secara khusus analisis laporan keungan, oleh karena, manajemen harus mempunyai model prediksi kebangkrutan sebagai peringatan dini sehingga bisa mengantisipasi kondisi perusahaan agar dalam keadaan sehat. Machine learning yang mempunyai kemampuan belajar dari data masa lalu sert menghasilkan solusi yang optimal dengan pendekatan pengenalan pola, akan digunakan dalam kajian ini. Algoritma Principle component analysi-based anomaly detection (PCA-BAD), Multiclass neural network dan Algoritma Perceptron akan digunakan untuk memecahkan masalah. Model yang dihasilkan diuji untuk memperoleh akurasi dan nilai-nilai AUC dari masing-masing algoritma. Nilai akurasi PCA-BAD nilai accuracy 53\% dan nilai AUC adalah 92\%. Sementara Multiclass Neural Network dengan threshold 1\% nilai Acuracy $100 \%$ dan AUC 100\%, sedangkan algoritma Perceptron Acuracy 100\% dan AUC 100\% Dengan demikian dapat disimpulkan bahwa model yang diusulkan adalah algoritma multiclass neural network.
\end{abstract}

Kata Kunci : Kebangkrutan, Machine learning, Prediksi

\begin{abstract}
Abstrac
Manufacturing Industry is one industry that is very concerned about financial statement analysis, therefore, management must have a bankruptcy prediction model as an initial publication that can promote the condition of the company to suit a healthy state. Machine learning that has the ability to learn from past data and produces optimal solutions by obtaining pattern recognition, will be used in this study. The main components of the analysis-based anomaly detection (PCA-BAD) algorithm, the Multiclass neural network and the Perceptron Algorithm will be used to solve the problem. The resulting model appreciates the accuracy and AUC values of each algorithm. The value of PCA-BAD accuracy is $53 \%$ and the AUC value is $92 \%$. While the Multiclass Neural Network with a threshold of 1\% Acuracy value 100\% and AUC 100\%, while the Perceptron Acuracy algorithm 100\% and AUC 100\% Thus it can be denied that the model used is a multiclass neural network
\end{abstract}

Keywords: Bankruptcy, machine learning, predictionManufaktur 


\section{PENDAhUluAN}

Topik kegagalan perusahaan telah menarik perhatian para peneliti dan menyebabkan beberapa studi tentang faktorfaktor yang mempengaruhi kegagalan keuangan atau keberhasilan perusahaan. Mempertimbangkan meningkatnya kompleksitas instrumen keuangan, semakin banyaknya emiten, dan sekuritisasi dan globalisasi; jelas bahwa akan ada peningkatan pada pihak-pihak yang berpotensi terkena kegagalan perusahaan. Dengan demikian, studi tentang prediksi kegagalan perusahaan akan terus menarik minat. Salah satu perbedaan inti di antara studi tentang topik ini adalah definisi kegagalan keuangan. Mengevaluasi literatur, aplikasi untuk kebangkrutan telah menjadi indikator kegagalan keuangan yang paling umum digunakan (Elam, 1975; Altman, Haldeman, \& Narayan, 1977; Ohlson, 1980; Zmijewski, 1983; Casey \& Bartczak, 1985; Beaver, Correia, \& McNichols, 2009; Wu, Gaunt, \& Gray, 2010; Jones \& Gambut, 2014).

Studi ini, menggunakan indikator kualitatif untuk mengidentifikasi perusahaan yang bangkrut, bertujuan untuk mengklasifikasikan perusahaan yang beroperasi di industri manufaktur sebagai bangkrut atau tidak bangkrut. Analisis diskriminan, regresi logistik, jaringan saraf tiruan, analisis komponen utama dan Decision Tree umumnya digunakan dalam literatur.

Penelitian ini menggunakan PCABAD, Multiclass neural network, dan algoritma Perceptron, yang merupakan algoritma dari Machine Learning yang bisa digunakan dalam klasifikasi dan studi estimasi.

\section{METODE PENELITIAN}

Data yang digunakan pada laporan ini semua berasal dari dataset Qualitative Bankcruptcy yang diambil dari laman https://archieve.ics.edu/ml/datasets/Qualitativ e+Bankcrupt. Data kualitatife kebangkrutan merupakan data kebangkrutan perusahaan manufaktur Mountesinho, Portugal yang terdiri dari 7 atribut (6 atribut/input dan 1 target estimasi/output), dan 250 record yang dapat dilihat pada Tabel 1.

Tabel 1. Dataset kualitatif kebangkrutan

\begin{tabular}{|c|c|c|c|c|c|c|}
\hline A & B & c & D & $\mathrm{E}$ & $\mathrm{F}$ & G \\
\hline Industrial_ & isk Management_Risk & Financial Flexibility & Credibility & Competitiveness & Operating Risk & k Category \\
\hline p & P & A & A & A & p & NB \\
\hline $\mathrm{N}$ & $\mathrm{N}$ & A & A & A & $\mathrm{N}$ & NB \\
\hline A & A & A & A & A & A & NB \\
\hline p & P & P & p & p & P & NB \\
\hline $\mathrm{N}$ & $\mathrm{N}$ & P & P & $p$ & $\mathrm{~N}$ & NB \\
\hline A & A & p & p & p & A & NB \\
\hline p & P & A & p & p & p & NB \\
\hline P & P & P & A & A & P & $B$ \\
\hline P & P & A & P & A & P & NB \\
\hline p & p & A & A & p & P & NB \\
\hline p & p & p & p & A & p & NB \\
\hline p & P & P & A & p & p & NB \\
\hline $\mathrm{N}$ & $\mathrm{N}$ & A & p & P & $\mathrm{N}$ & NB \\
\hline $\mathrm{N}$ & $\mathrm{N}$ & P & A & A & N & NB \\
\hline $\mathrm{N}$ & $\mathrm{N}$ & A & P & A & $\mathrm{N}$ & NB \\
\hline $\mathrm{N}$ & $\mathrm{N}$ & A & p & A & $\mathrm{N}$ & NB \\
\hline N & $\mathrm{N}$ & A & A & $p$ & $\mathrm{~N}$ & NB \\
\hline $\mathrm{N}$ & $\mathrm{N}$ & P & p & A & $\mathrm{N}$ & NB \\
\hline $\mathrm{N}$ & $\mathrm{N}$ & P & A & p & $\mathrm{N}$ & NB \\
\hline A & A & A & p & p & A & NB \\
\hline A & A & p & A & A & A & NB \\
\hline A & A & A & p & A & A & NB \\
\hline , & Qualititive _Bankcrupte & (†) & & & & \\
\hline
\end{tabular}

Semua data yang digunakan berisikan tentang data - data perusahaan yang sedang mengalami kebangkrutan dan yang tidak. Dataset menggugunakan parameter kualitatif. Dimana setiap atribut bernilai Positive, Average, dan Negative. $(P=$ Positive, $A$-Average, $N$-negative, $B$ Bankruptcy,NB-Non-Bankruptcy)

1)IndustrialRisk:

$\{P, A, N\}$

2)ManagementRisk:

$\{P, A, N\}$

3)FinancialFlexibility:

$\{P, A, N\}$

4)Credibility:

$\{P, A, N\}$

5)Competitiveness:

$\{P, A, N\}$

6)OperatingRisk:

7)Class: $\{B, N B\}$

$\{P, A, N\}$

Akurasi prediksi keseluruhan percobaan pada penelitian ini menggunakan RMSE dan Kurva ROC. Metrik yang kami gunakan untuk mengukur akurasi predikai adalah nilai root mean square error (RMSE). RMSE sangat populer untuk menilai algoritma mesin pembelajaran, termasuk algoritma yang jauh lebih canggih dari perceptronr (Conway \& White, 2012). Nilai RMSE digunakan untuk membedakan kinerja model dalam periode kalibrasi dengan periode validasi serta untuk membandingkan kinerja model individual dengan model prediksi lainnya (Hosseini, Javaherian, \& Movahed, 2014), dan kami juga menggunakan uji yang Sensitivitas, Spesifisitas, Positive Predictive Value, Negative Predictive Value, Akurasi Kurva ROC - Nilai cut-off. 
JURNAL BUFFER INFORMATIKA

Volume 5 Nomor 1, April 2019

\subsection{Tahapan Review}

\subsubsection{Gambar dan Tabel}

Tabel 2. Atribut dan Diskripsi

\begin{tabular}{|c|c|}
\hline Atribut & Deskripsi \\
\hline $\begin{array}{l}\text { IndustryRisk } \\
\text { (IR) }\end{array}$ & $\begin{array}{|lrr|}\text { Aturan } & \text { pemerintahan } & \text { dan } \\
\text { persetujuan } & \text { internasional, } \\
\text { Tingkat } & \text { Persaingan, Harga dan } \\
\text { stabilitas } & \text { pasokan } & \text { pasar, } \\
\text { Ukuran } & \text { dan } & \text { pertumbuhan } \\
\text { permintaan } & \text { pasar, Kepekaan } \\
\text { terhadap } & \text { perubahan } & \text { faktor } \\
\text { ekonomi } & \text { makro, daya saing } \\
\text { domestik } & \text { dan internasional, }\end{array}$ \\
\hline $\begin{array}{l}\text { Management } \\
\text { risk (MR) }\end{array}$ & $\begin{array}{l}\text { Kemampuan dan } \begin{array}{r}\text { kompetensi } \\
\text { manajemen, }\end{array} \\
\text { manajemen, Hubungan antara } \\
\text { manajemen }\end{array}$ \\
\hline $\begin{array}{l}\text { Financial } \\
\text { Flexibility } \\
\text { (FF) }\end{array}$ & $\begin{array}{l}\text { Pembiayaan } \\
\text { langsung,pembiayaan tidak } \\
\text { langsung, pembiayaan lainnya }\end{array}$ \\
\hline $\begin{array}{l}\text { Kredibility } \\
(\mathrm{CR})\end{array}$ & $\begin{array}{l}\text { Sejarah kredit, keandalan } \\
\text { informasi, Hubungan dengan } \\
\text { lembaga keuangan. }\end{array}$ \\
\hline $\begin{array}{l}\text { Competi- } \\
\text { tiveness }(\mathrm{CO})\end{array}$ & $\begin{array}{l}\text { Posisi pasar, Tingkat kapasitas } \\
\text { inti, Perbedaan strategi }\end{array}$ \\
\hline $\begin{array}{l}\text { Operating } \mathrm{R} \\
(\mathrm{OP})\end{array}$ & $\begin{array}{l}\text { Stabilitas } \\
\text { pengadaan, }\end{array}$ \\
\hline Class & Status kebangkrutan \\
\hline
\end{tabular}

p-ISSN : 2527-4856, e-ISSN : 2614-5413

https://journal.uniku.ac.id/index.php/buffer

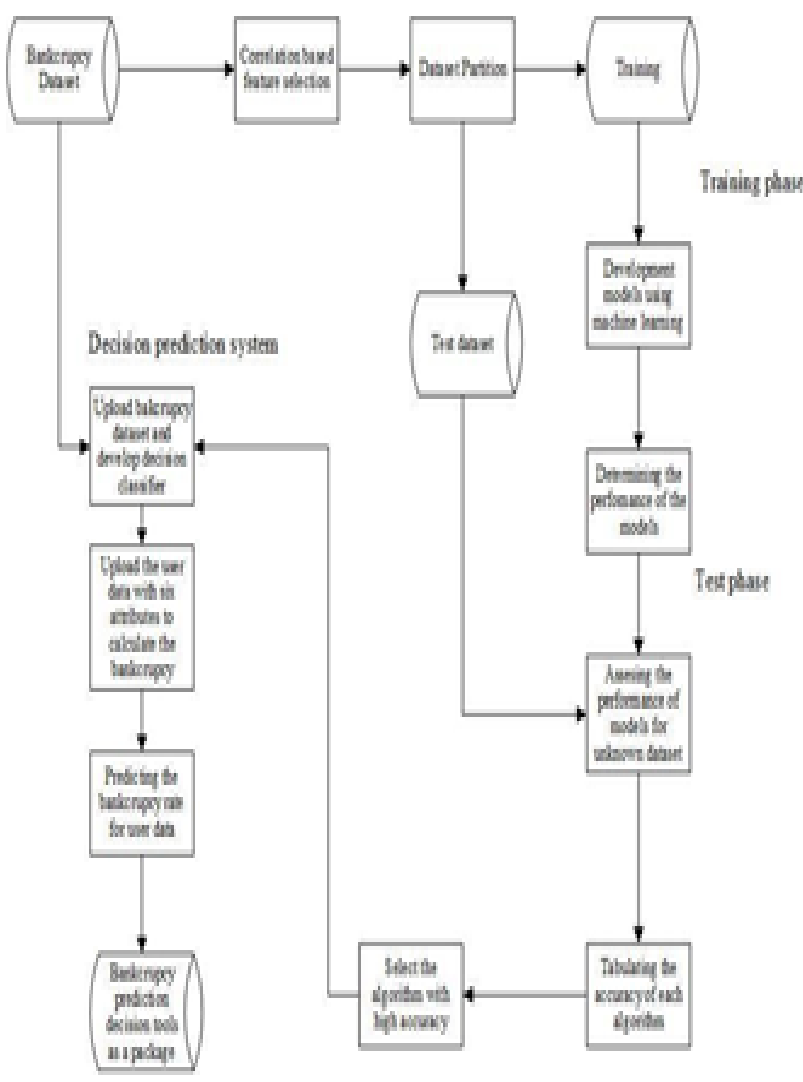

Gambar 1. Gambaran Umum Sistem

\subsection{Formulir Copyright}

Formulir copyright harus disertakan pada pengiriman naskah akhir. Anda bisa meminta versi .pdf, atau .doc via email ke xxxxxx@gmail.com

\subsubsection{Rumus Matematika}

\section{Algoritma Principal Component Analysis. \\ Principal Componen Analysis atau} yang lebih populer dikenal dengan singkatannya 'PCA', adalah sebuah metode statistik yang banyak digunakan dalam sistem pengenalan pola (wajah, karakter, dll) serta kompresi citra. PCA pada dasarnya bekerja pada sekelompok data observasi yang pada awalnya memiliki kemungkinan saling berelasi, kemudian proses PCA mengkonversi data tersebut sedemikian rupa sehingga yang tersisa adalah data yang tidak saling berelasi satu sama lain yang disebut dengan Principal Component. 
Jumlah Principal Component yang dihasilkan adalah kurang dari atau sama dengan jumlah data aslinya. Principal Component akan diurutkan dari data yang dianggap paling penting sampai data yang kurang penting. Sederhananya, data pada baris pertama hasil konversi adalah Principal Component pertama dan yang paling berpengaruh terhadap variasi data asli. Proses PCA dapat dilakukan dengan 2 cara:

1. Menggunakan eigen function daric ovarian-nya.

2. Menggunakan SVD (Singular Value Decomposition).

Algoritma Multiclass Neural Network.

Jaringan Syaraf Tiruan (Arifical Neural Network) atau yang dikenal dengan istilah Neural Network (NN) merupakan sistem pemroses informasi yang memiliki karakteristik mirip dengan syaraf biologi, dimana dalam memproses informasi, otak manusia terdiri dari sejumlah neuron yang melakukan fungsi pemrosesan cukup kompleks. Pemrosesan informasi pada manusia bersifat adaptif, yang artinya hubungan antar neuron terjadi secara dinamis dan selalu memiliki kemampuan untuk mempelajari informasi-informasi yang belum diketahui sebelumnya [3].

Secara garis besar pada $\mathrm{NN}$ memiliki dua tahap pemrosesan informasi, yaitu tahap pelatihan dan tahap pengujian. Tahap pelatihan dimulai dengan memasukkan pola-pola belajar (data latih) ke dalam jaringan.

\section{Algoritma Perceptron.}

Perceptron adalah salah satu metode Jaringan Syaraf Tiruan (JST) sederhana yang menggunakan algoritma training untuk melakukan klasifikasi secara linier. Perceptron digunakan untuk melakukan klasifikasi sederhana dan membagi data untuk menentukan data mana yang masuk dalam klasifikasi dan data mana yang missclasifikasi (diluar klasifikasi). Perceptron dapat kita gunakan untuk memisahkan data yang dapat kita bagi menjadi 2 kelas, misalnya kelas sukses dan kelas belum sukses.
Perceptron dalam Jaringan Syaraf Tiruan memiliki bobot yang bisa diatur dalam suatu ambang batas (threshold). Melalui proses pembelajaran, Algotirma perceptron akan mengatur parameter-parameter bebasnya.

\section{HASIL DAN PEMBAHASAN}

\subsection{Algoritma PCA}

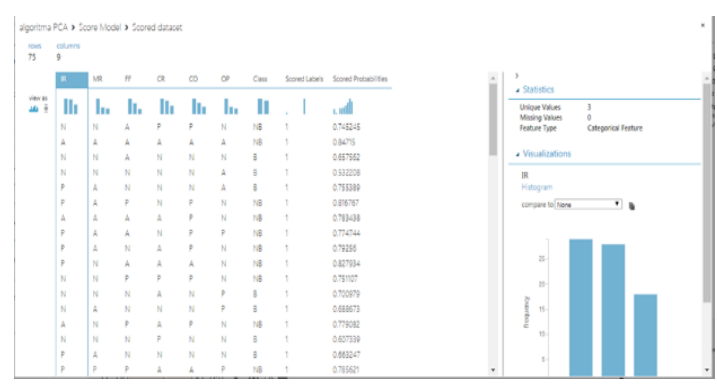

Gambar 2. Grafik Score PCA

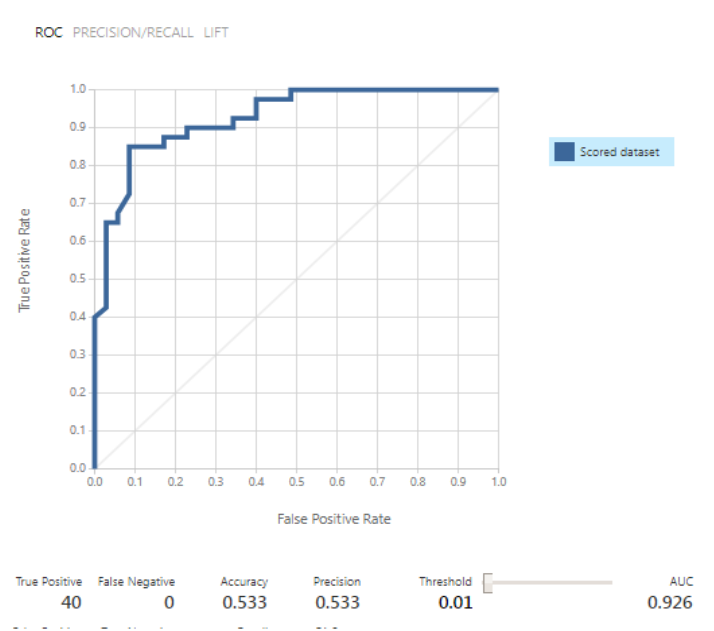

Gambar 3. ROC CURVE Hasil PCA

Nilai AUC adalah 0,92, itu berarti ada kemungkinan $92 \%$ bahwa model akan dapat membedakan antara kelas bankcrupt dan non bankcrupt. Nilai Acuracy 53\% mengacu pada seberapa dekat nilai yang diukur dengan nilai sebenarnya. Presisi mempunyai nilai 53\% mengacu pada seberapa dekat nilai yang diukur satu sama lain. 


\subsection{Algoritma Multiclass Neural Network}

Inisialisasi algoritma, learning rate 0.1 , threshold 0.01 dan 100 learning itteration. Hasil evaluasi data testing adalah sebagai berikut :

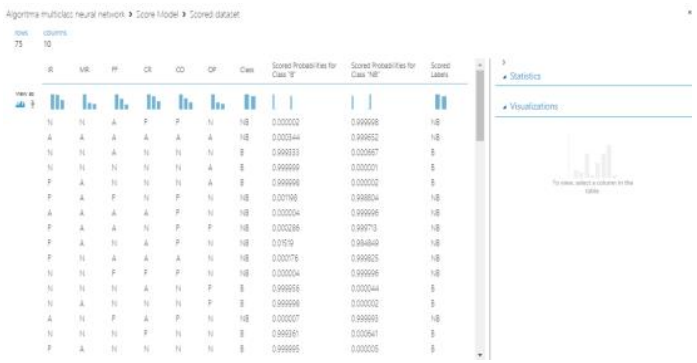

Gambar 4. Grapik Score MNN

\begin{tabular}{ll}
\hline Overall accuracy & 1 \\
Average accuracy & 1 \\
Micro-averaged precision & 1 \\
Macro-averaged precision & 1 \\
Micro-averaged recall & 1 \\
Macro-averaged recall & 1 \\
& \\
\hline Confusion Matrix & \\
\hline
\end{tabular}

Predicted Class

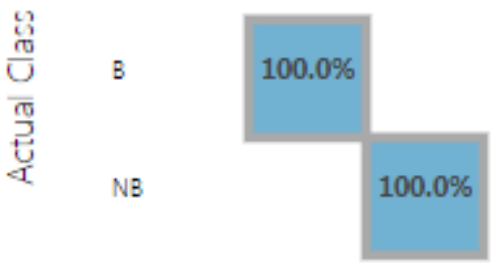

Gambar 5. Evaluasi Model MNN

Nilai Accurarcy $100 \%$ menandakan ketepatan kepada nilai yang diukur, sedangkan acuracy $100 \%$, itu berarti ada kemungkinan $100 \%$ bahwa model akan dapat membedakan antara kelas bankcrupt dan non bankcrupt.

\subsection{Algoritama Perceptron}

Inisialisasi algoritma, learning rate 0.1 , threshold 0.01 dan 100 learning itteration. Hasil evaluasi data testing adalah sebagai berikut :

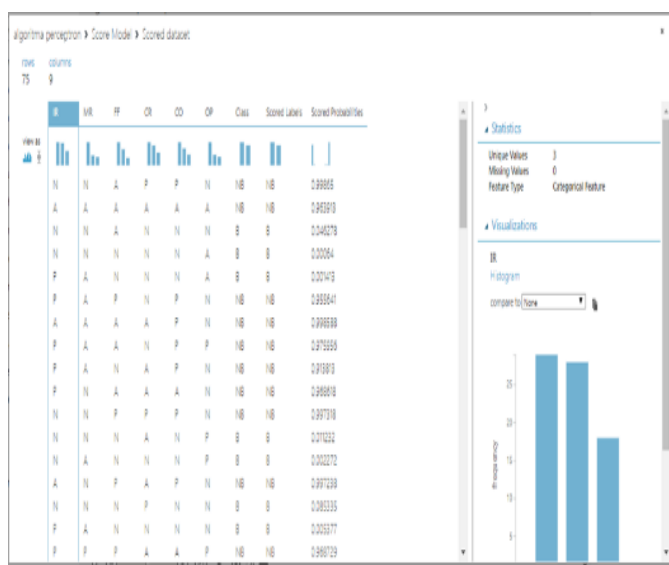

Gambar 6. Grapik Perceptron 1

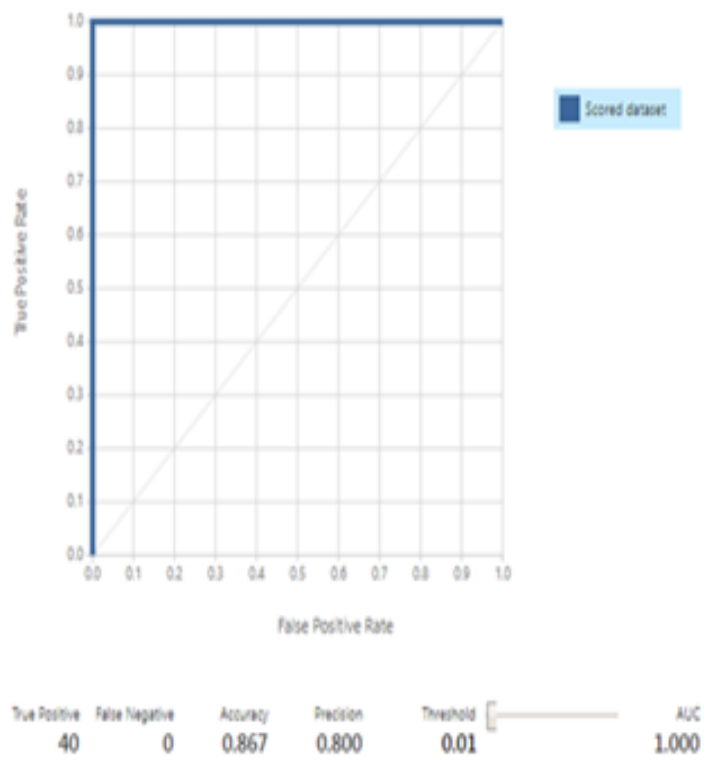

Gambar 7. Grapik Perceptron 2

NilaiAccurarcy $100 \%$ menandakan ketepatan kepada nilai yang diukur, sedangkan precision $100 \%$, itu berarti ada kemungkinan $100 \%$ bahwa model akan dapat membedakan antara kelas bankcrupt dan non bankcrupt. Nilai AUC adalah $100 \%$, ini menandakan kualitas model prediksinya benar $100 \%$ terlepas dari ambang klasifikasi apa yg dipilih.

\section{KESIMPULAN}

Makalah ini membandingkan akurasi peramalan algoritma machine learning untuk memprediksi kebangkrutan perusahaan manufaktur yang ada di Amerika. Dataset semua berasal dari https://archive.ics.uci.edu/ml/datasets//quali tative bankruptcy 
Hasil empiris menunjukkan bahwa algoritma machine learning memiliki tingkat ke akuratan yang berbeda antara algoritma PCA, MCNN dan Linier Regression.

Tabel 2. Hasil Algoritma Machine Learning

\begin{tabular}{|l|l|l|l|}
\hline No. & \multicolumn{1}{|c|}{ Algoritma } & \multicolumn{1}{|c|}{$\begin{array}{c}\text { Accuracy } \\
\%\end{array}$} & $\begin{array}{c}\text { AUC } \\
(\%)\end{array}$ \\
\hline 1 & $\begin{array}{l}\text { Principal } \\
\text { Componen } \\
\text { Analysis }\end{array}$ & 53 & 92 \\
\hline 2 & $\begin{array}{l}\text { Multiclass } \\
\text { Neural } \\
\text { Network }\end{array}$ & 100 & 100 \\
\hline 3 & Perceotron & 100 & 100 \\
\hline
\end{tabular}

Di masa depan, kami berencana untuk memperluas kajian kami ke lebih banyak indikator perusahaan. Dengan perkembangan pasar modal Amerika, akan ada lebih banyak karakteristik perusahaan yang akan diungkapkan. Berdasarkan tren ini, kami akan memilih lebih banyak indikator untuk memprediksi kebangkrutan. Selain itu, kami akan menerapkan metode ini ke lebih banyak perusahaan kecil dan menengah di Indonesia Selanjutnya, kami akan mencoba lebih banyak metode pembelajaran mesin dan meningkatkan akurasi prediksikebangkrutan.

\section{SARAN}

Saran-saran untuk untuk penelitian lebih lanjut untuk menutup kekurangan penelitian. Tidak memuat saran-saran diluar untuk penelitian lanjut.

\section{DAFTAR PUSTAKA}

[1] Castleman, [1] N. Öcal, M. K. Ercan and E. Kadığlu, "Predicting Financial Failure Using Decision Tree Algorithms: An," International Journal of Economics and Finance, vol. 7, pp. 189-206, 2015.

[2] "Popular Decision Tree: CHAID Analysis, Automatic Interaction Detection," $\quad$ Statsoft, 2018.
[Online].Available:

http://www.statsoft.com/Textbook/C

HAID-Analysis. [Accessed 17

Desember 2018].

[3] Wyatt, J. C, danSpiegelhalter, D., 1991, Field Trials of Medical Decision-Aids: PotentialProblems and Solutions, Clayton, P. (ed.): Proc. 15th Symposium on ComputerApplications in Medical Care, Vol 1, Ed. 2, McGraw Hill Inc, New York.

[4] Yusoff, M, Rahman, S.,A., Mutalib, S., and Mohammed, A. , 2006, Diagnosing Application Development for Skin Disease Using Backpropagation Neural Network Technique, Journal of Information Technology, vol 18, hal 152-159.

[5] Wyatt, J. C, Spiegelhalter, D, 2008, Field Trials of Medical Decision-Aids: PotentialProblems and Solutions, Proceeding of 15th Symposium on ComputerApplications in Medical Care, Washington, May 3.

[6] Prasetya, E., 2006, Case Based Reasoning untuk mengidentifikasi kerusakan bangunan, Tesis, Program Pasca Sarjana Ilmu Komputer, Univ. Gadjah Mada, Yogyakarta.

[7] Ivan, A.H., 2005, Desain target optimal, Laporan Penelitian Hibah Bersaing,Proyek Multitahun, Dikti, Jakarta.

[8] Wallace, V. P., Bamber,J. C. dan Crawford, D. C. 2000. Classification of reflectance spectra from pigmented skin lesions, a comparison of multivariate discriminate analysis and artificial neural network. Journal Physical Medical Biology , No.45, Vol.3, 2859-2871.

[9] Xavier Pi-Sunyer, F., Becker, C., Bouchard, R.A., Carleton, G. A., Colditz, W., Dietz, J., Foreyt, R. Garrison, S., Grundy, B. C., 1998, Clinical Guidlines on the identification, evaluation, and treatment of overweight 
and obesity in adults, Journal of National Institutes of Health, No.3, Vol.4, 123-130, :http://journals.lww.com/acsmmsse/Abstract/1998/11001/paper_treat ment_of_obesity.pdf.

[10] Borglet, C, 2003,Finding Asscociation Rules with Apriori Algorithm,http://www.fuzzy.cs.uniag deburgde/ borglet/apriori.pdf, diakses tgl 23 Februari 2007.

[11] Sri Kusumadewi. Buku ajar Kecerdasan Buatan, Teknik Informatika UII, Yogyakarta, 2002.

[12] Sutikno., 2010. Algoritma JST Backpropagation \& implementasinya [online]

http://sutikno.blog.undip.ac.id/files/.../2 1-Algoritma-JST-backpropagation , diakses tanggal 23 Mei 2011).

[13] NN., 2009. Aplikasi Jaringan Syaraf Tiruan sebagai Metode Alternatif Prakiraan Beban Jangka Pendek [online] http://www.elektroindonesia.com/elek tro/ener29.html, diakses 23 Mei 2011).

[14] NN., 2011. JST Backprogagation Project [online] (http://simplyknowledge.wordpress.co m/2011/01/22/jst-backproaation/, diakses tanggal 23 Mei 2011).

[15] Alareeni, BA, \& Branson, J. (2012). Memprediksi kegagalan emiten di Yordania menggunakan model Altman: Sebuah studi kasus. International Journal of Bisnis dan Manajemen, 8 (1), p113.

[16] Al-hroot, Y. (2015), Pengaruh ukuran sampel dan pemilihan rasio keuangan dalam akurasi Model kebangkrutan Economic Review: Jurnal Ekonomi dan Bisnis, 2015; XIII (1) 7-19.
[17] Alkhatib, K., \& Al Bzour, AE (2011). Memprediksi kebangkrutan perusahaan dari perusahaan yang terdaftar Yordania: Menggunakan Altman dan Kida model. International Journal of Bisnis dan Manajemen, 6 (3), p208.

[18] Fitzpatrick, Paul J., Ph.D. 'A Perbandingan Rasio Sukses Usaha Industri Dengan Mereka perusahaan Gagal'. Certified Public Accountant Beaver 1968. Journal of AKUNTANSI Research. (Dalam tiga isu:... Oktober, 1932, p 598-605;

November, 1932 , p 656-662; Desember 1932, p 727-731)

[19] Gosavi, A. (2015). Optimasi Simulasi Berbasis: Sebuah Tinjauan. Dalam Optimasi Simulasi Berbasis (pp. 2935). Springer AS.

[20] Goss, EP, \& Ramchandani, H. (1995). Membandingkan akurasi klasifikasi jaringan saraf, logit regresi binary dan analisis diskriminan untuk prediksi kepailitan perusahaan asuransi jiwa. Jurnal Ekonomi dan Keuangan, 19 (3), 1-18.

[21] Karamzadeh, MS (2013). Aplikasi dan Perbandingan Altman dan Ohlson Model untuk Memprediksi Kebangkrutan perusahaan. Penelitian Journal of Applied Sciences, Rekayasa dan Teknologi, 5 (6), 20072011.

[22] Koh, HC, \& Tan, SS (1999). Pendekatan jaringan saraf untuk prediksi akan statusnya perhatian. Akuntansi dan Penelitian Bisnis, 29 (3), 211-216. Mehrazin, Alireza, et al. "Basis Function Radial di Artificial Neural Network untuk Prediksi Kepailitan." International Business Research 6,8 (2013): p121. 
JURNAL BUFFER INFORMATIKA

Volume 5 Nomor 1, April 2019
p-ISSN : 2527-4856, e-ISSN : 2614-5413

https://journal.uniku.ac.id/index.php/buffer

[24] Odom, MD, \& Sharda, R. (1990). Sebuah model jaringan saraf untuk prediksi kebangkrutan. Pada tahun 1990 IJCNN Konferensi Internasional Bersama jaringan saraf (pp. 163-168).

[25] Ohlson, JA (1980). rasio keuangan dan prediksi probabilistik kebangkrutan. Jurnal penelitian akuntansi, 109-131. 